\title{
ANALISIS IMPLEMENTASI GOOD CORPORATE GOVERNANCE PADA PT INDUSTRI TELEKOMUNIKASI INDONESIA
}

\section{IMPLEMENTATION ANALYSIS OF GOOD CORPORATE GOVERNANCE IN PT INDUSTRI TELEKOMUNIKASI INDONESIA}

\author{
Rudy Hartanto', Helni Mutiarsih Jumhur ${ }^{2}$ \\ ${ }^{1}$ Prodi S1 Manajemen Bisnis Telekomunikasi dan Informatika, Fakultas Ekonomi dan \\ Bisnis,Universitas Telkom \\ ${ }^{2}$ Staff Pengajar Fakultas Ekonomi dan Bisnis, Universitas Telkom \\ 1hartanto.rudy27@gmail.com, 2helni.mutiarsih@gmail.com
}

\begin{abstract}
Abstrak
Salah satu upaya perusahaan dalam memaksimalkan nilai adalah melalui pemisahan kepemilikan dari pengelolaan perusahaan. Melalui pemisahan ini kegiatan pengelolaan diharapkan lebih fokus dengan ditangani oleh pihak yang profesional. Meskipun mampu memberikan efektifitas dalam pengelolaan perusahaan, pemisahan ini juga menimbulkan masalah yang dikenal sebagai agency problem. Untuk melindungi kepentingan pemegang saham dibutuhkan suatu struktur dan proses yang mengarahkan dan mengelola kegiatan perusahaan secara menyeluruh untuk kepentingan pemegang saham dan tetap memperhatikan kepentingan pemangku kepentingan lain. Struktur dan proses inilah yang disebut Good Corporate Governance (GCG). Penelitian ini bertujuan mengetahui implementasi GCG melalui penerapan prinsip-prinsip yang terkandung dalam GCG. Prinsip-prinsip yang digunakan berdasarkan Surat Keputusan Menteri BUMN No. Kep-117/M-MBU/2002 tentang Penerapan Praktik GCG pada BUMN yang meliputi transparansi, kemandirian, akuntabilitas, pertanggungjawaban, dan kewajaran. Jenis penelitian yang digunakan adalah deskriptif kuantitatif. Analisis data menggunakan penghitungan sesuai corporate governance self assessment checklist. Untuk interpretasi hasil perhitungan presentase menggunakan ketentuan Dean J Champion. Hasil penelitian menunjukkan implementasi prinsip transparansi, akuntabilitas, pertanggungjawaban dan kewajaran berada pada kategori sangat memadai, hanya prinsip kemandirian yang penerapannya cukup memadai. Untuk implementasi GCG secara keseluruhan presentase nilai yang didapatkan adalah $83,70 \%$ yang berarti penerapan GCG pada PT INTI telah sangat memadai.
\end{abstract}

Kata kunci : Good Corporate Governance, Corporate Governance Self Assessment Checklist.

\begin{abstract}
One of the company's efforts in maximizing the value is through separation of ownership from management companies. Through this separation, management activities are expected to be more focused and to be handled by the professionals. Although the separation is able to provide effectiveness in managing the company, this also creates a problem known as the agency problem. To protect the interests of shareholders we need a structure and process of directing and managing the overall activities of the company for the sake of shareholders and still consider the interests of other stakeholders. The structure and the process is called Good Corporate Governance (GCG). This study aims to determine the GCG implementation through application of the principles contained in the GCG. The principles used by the Minister of State-Owned Enterprises No. "Kep-117 / M-MBU / 2002" concerning
\end{abstract}


the Implementation and Practice of GCG in SOEs which include transparency, independence, accountability, responsibility, and fairness. The type of the research is descriptive quantitative research. Data analysis using appropriate calculation of corporate governance self-assessment checklist. For the interpretation of the results of the calculation of the percentage is based on the provision Dean J Champion. The results show the implementation of the principles of transparency, accountability, responsibility and fairness in the category is more than adequate, only the application of the principle independence that category is just adequate. For the overall implementation GCG, the percentage of the value obtained was $83.70 \%$, which means the application of GCG at PT INTI has been very adequate.

Keywords: Good Corporate Governance, Corporate Governance Self-Assessment Checklist.

\section{Pendahuluan}

Peningkatan nilai perusahaan yang tinggi tentu menjadi harapan dan tujuan jangka panjang bagi setiap perusahaan. Dalam proses memaksimalkan nilai tersebut, pengelolaan perusahaan harus ditangani secara tepat dan profesional. Salah satunya adalah dengan memisahkan kepemilikan dari pengelolaan perusahaan. Dengan pemisahan ini kegiatan pengelolaan diharapkan lebih fokus dengan ditangani oleh pihak yang profesional. Meskipun mampu memberikan efektifitas dalam pengelolaan perusahaan, pemisahan antara kepemilikan dan pengelolaan perusahaan dapat menimbulkan masalah yang dikenal sebagai agency problem. Seperti yang diungkapkan oleh Jensen dan Meckling (Warsono et al, 2009:10), agency problem adalah masalah yang muncul karena perbedaan informasi antara pemegang saham sebagai pihak yang memberikan amanat dengan manajemen sebagai pihak yang menerima amanat untuk mengelola perusahaan. Salah satu masalah dalam agency problem adalah perbedaan kepentingan antara pemegang saham dengan manajemen. Sebagai contoh, untuk meningkatkan bonus maka manajemen mungkin akan memoles laporan keuangannya sehingga kinerja perusahaan tampak lebih baik dari yang sebenarnya. Apabila laporan keuangan tidak akurat maka keputusan investasi yang diambil oleh pemegang saham menjadi tidak tepat. Pada akhirnya hal ini menyebabkan keinginan pemegang saham untuk memperoleh tingkat keuntungan tertentu menjadi tidak tercapai. Untuk melindungi kepentingan pemegang saham harus terdapat suatu struktur dan proses yang mengarahkan dan mengelola kegiatan perusahaan secara menyeluruh untuk kepentingan pemegang saham dan dengan memperhatikan kepentingan pemangku kepentingan lain. Struktur dan proses inilah yang disebut dengan Good Corporate Governance. Secara umum, Good Corporate Governance (GCG) dapat dijabarkan menjadi beberapa prinsip yaitu Transparansi, Akuntabilitas, Pertanggungjawaban, Independensi, serta Kesetaraan dan Kewajaran (Komite Nasional Kebijakan Governance, 2006).

Di Indonesia, konsep GCG mulai banyak dibicarakan ketika terjadi krisis moneter pada tahun 1997. Krisis yang terjadi di Indonesia mengakibatkan banyak perusahaan tidak mampu bertahan, hal tersebut tercermin dari 16 bank yang dengan terpaksa harus dilikuidasi karena tidak mampu mempertahankan kelangsungan usahanya. Dalam kajiannya, Bank Pembangunan Asia menarik kesimpulan bahwa krisis ekonomi yang menimpa negara-negara di Asia Tenggara utamanya disebabkan karena sistem corporate governance yang buruk dalam perekonomian. Praktik-praktik corporate governance yang kurang terpuji sering ditandai dengan ciri-ciri dewan direksi yang tidak efektif, kontrol internal yang lemah, audit yang buruk, kurangnya disclosure yang seimbang, dan kurangnya penegakan hukum (Sutedi, 2011:50).

Tuntutan pelaksanaan GCG di Indonesia utamanya ditujukan kepada Badan Usaha Milik Negara (BUMN). Hal ini didorong oleh komitmen pemerintah untuk menciptakan 
BUMN yang berkualitas global dan efisien dalam pengelolaannya. Banyaknya jumlah BUMN di Indonesia dengan hasil kinerja secara keseluruhan yang kurang menggembirakan dianggap hanya akan membebani anggaran negara (APBN). Menghadapi kondisi tersebut pemerintah Indonesia melakukan tindakan dengan perampingan jumlah BUMN yang telah dimulai sejak tahun 2007. Secara perlahan namun pasti jumlah BUMN mulai dikurangi dari semula berjumlah 140 tersisa 104 ditahun 2007, kemudian turun menjadi 87 pada tahun 2008, lalu tinggal 69 ditahun 2009 dan direncanakan hanya akan tersisa sebanyak 25 BUMN di Indonesia pada tahun 2015. BUMN perlu diatur serta dikelola secara efektif dan efisien sesuai dengan mekanisme GCG karena memiliki peran yang signifikan terhadap perekonomian nasional sebagai aparatur perekonomian negara. Namun, pada kenyataannya belum semua BUMN di Indonesia telah melaksanakan praktek GCG dengan sepenuhnya. Umumnya pelaksanakan GCG dikarenakan tuntutan regulasi saja tanpa praktik yang benar dan berkesinambungan dari nilai yang terkandung dalam prinsip GCG. Guna memaksimalkan implementasi GCG pada BUMN, pemerintah Indonesia menerbitkan Surat Keputusan Menteri BUMN No. Kep-117/M-MBU/2002 Tangal 31 Juli Tahun 2002 tentang Penerapan Praktik GCG pada BUMN. Konsep terkait GCG juga tertuang dalam pion IV dan poin VI dari penjelasan atas Undang-Undang No.19 Tahun 2003 tentang BUMN (Effendi, 2009:61).

GCG merupakan hal yang esensial untuk diterapkan pada BUMN. Implementasi GCG serta tanggungjawab sosial perusahaan diyakini mampu menjadikan sebuah perusahaan lebih bernilai dan dihargai. Penelitian yang dilakukan oleh Mc Kinsey \& Company (Mukharomah, 2010) membuktikan bahwa para manajer dana di Asia akan membayar 26-30\% lebih untuk saham-saham perusahaan dengan GCG yang lebih baik daripada untuk saham-saham perusahaan dengan GCG yang meragukan. Hal senada juga disampaikan oleh Komite Nasional Kebijakan Governance (KNKG) bahwa pedoman GCG yang disusun oleh lembaga tersebut antara lain bertujuan untuk memaksimalkan nilai perusahaan dan nilai perseroan bagi pemegang saham dengan penerapan prinsip-prinsip yang terkandung dalam GCG.

PT INTI merupakan perusahaan yang bergerak di bidang industri dan rekayasa telekomunikasi. Pada tahun 1990-an PT INTI adalah perusahaan besar yang berjaya pada sektor manufaktur telekomunikasi. Namun memasuki tahun 2000 PT INTI mengalami penurunan kinerja dan oleh Kementrian BUMN digolongkan kedalam BUMN yang kurang berkembang. PT INTI juga sempat akan dimasukkan kedalam sebuah strategic holding bersama BUMN lainnya seperti PT Krakatau Steel, PT Barata Indonesia, PT LEN Industri dan PT PAL Indonesia. Berbanding terbalik dengan keadaan tersebut, sekarang PT INTI kembali tumbuh dengan kinerja perusahaan yang terus meningkat. Kinerja PT INTI yang terus meningkat dapat dilihat dari laporan keuangan perusahaan yang terus mengalami peningkatan pada pendapatan dan juga keuntungan perusahaan. Berikut gambaran peningkatan kinerja PT INTI dalam Tabel 1 :

\begin{tabular}{|c|l|c|c|c|}
\hline No. & Uraian & $\mathbf{2 0 1 0}$ & $\mathbf{2 0 1 1}$ & $\mathbf{2 0 1 2}$ \\
\hline 1. & Penjualan & $647.815,0$ & $723.117,0$ & $1.227 .699,7$ \\
\hline 2. & Laba Bersih & 4.586 & 10.226 & $16.331,7$ \\
\hline 3. & Ekuitas & $412.932,0$ & $419.669,7$ & $434.569,8$ \\
\hline 4. & Jumlah Aset & $637.941,6$ & $1.001 .006,4$ & $1.070 .232,1$ \\
\hline
\end{tabular}

Dari data yang disajikan pada Tabel 1 diperoleh informasi bahwa selama kurun waktu tiga tahun yaitu tahun 2010 sampai dengan 2012, penjualan PT INTI selalu mengalami kenaikan yang cukup signifikan dan tentunya hal tersebut diikuti oleh laba yang diperoleh 
perusahaan yang juga terus mengalami peningkatan. Hal tersebut membuktikan bahwa PT INTI masih menunjukan eksistensinya dalam persaingan bisnis di sektor industri telekomunikasi.

Sebagai BUMN, PT INTI telah menerapkan GCG dalam kegiatan pengelolaan perusahaan. Bagi PT INTI, GCG telah menjadi bagian dalam strategi perusahaan yang digunakan sebagai peningkat keberhasilan usaha. Proses pelaksanaan GCG telah dimulai sejak tahun 2004 dengan dibentuknya Komite Tata Kelola Perusahaan untuk membangun dasar penerapan GCG. Implementasi GCG INTI dapat dilihat pada kegiatan sehari-hari perusahaan yang antara lain telah menerapkan E-auction guna transparansi pengadaan barang dan jasa, memberdayakan website INTI untuk keterbukaan informasi, publikasi laporan keuangan perusahaan, perbaikan berbagai peraturan. Untuk mempertahankan dan bahkan meningkatkan standar pencapaian praktek GCG pada PT INTI dilakukan kegiatan monitoring dan evaluasi praktek GCG secara teratur dan berkesinambungan.

Penelitian ini bertujuan untuk mengetahui gambaran implementasi GCG yang dilakukan oleh PT INTI. Pengukuran variabel GCG dilakukan menggunakan pedoman Corporate Governance Self Assessment Checklist yang dikeluarkan oleh KNKG. Pedoman tersebut digunakan karena manfaat dari Corporate Governance Self Assessment Checklist ini secara internal perusahaan cukup besar sehingga mampu menggambarkan implementasi yang dilakukan oleh perusahaan serta mampu mengidentifikasi bagian dari implementasi GCG yang masih lemah pada perusahaan agar dapat ditanggulangi.

\section{Tinjauan Pustaka}

Gede Raka dalam Effendi (2009:6) menjelaskan pada konsep Good Corporate Governance (GCG) memiliki arti secara tersirat bahwa sebuah perusahaan bukanlah sekedar mesin pencetak keuntungan bagi pemiliknya, akan tetapi perusahaan adalah sebuah entitas yang diharapkan dapat menciptakan nilai bagi seluruh pihak yang berkepentingan. Konsep yang dibawa GCG sesungguhnya mencerminkan pentingnya sikap berbagi, peduli dan melestarikan.

Kata "governance" berasal dari bahasa perancis yaitu "gubernance" yang berarti pengendalian. Kemudian kata tersebut digunakan dalam konteks kegiatan perusahaan atau jenis organisasi yang lain menjadi corporate governance. Dalam bahasa Indonesia corporate governance diterjemahkan sebagai tata kelola atau tata pemerintahan perusahaan (Effendi, 2009:1). Pasal 1 Surat Keputusan Menteri BUMN No. 117/M-MBU/2002 Tanggal 31 Juli 2002 tentang penerapan GCG pada BUMN memberikan pengertian bahwa GCG adalah sebuah proses dan struktur yang digunakan BUMN untuk meningkatkan keberhasilan usaha dan akuntabilitas perusahaan guna mewujudkan nilai pemegang saham dalam jangka panjang dengan tetap memperhatikan pemangku kepentingan lainnya, berlandaskan peraturan perundangan dan nilai-nilai etika. Secara singkat GCG diartikan sebagai seperangkat sistem yang digunakan guna mengatur dan mengendalikan perusahaan dengan tujuan untuk menciptakan nilai tambah bagi para pemangku kepentingan (Effendi, 2009:2).

Sejalan dengan yang tertera dalam Pedoman Umum Good Corporate Governance Indonesia (2006) yang dikeluarkan oleh Komite Nasional Kebijakan Governance (KNKG) bahwa guna menjaga kesinambungan (sustainability) usaha serta tetap memperhatikan kepentingan pemangku kepentingan (stakeholders), perusahaan harus memastikan bahwa setiap prinsip dalam GCG yaitu transparansi, kemandirian, akuntabilitas, pertanggungjawaban dan kewajaran telah diterapkan pada setiap aspek bisnis dan disemua jajaran perusahaan. Prinsip-prinsip tersebut memiliki peran sebagai pijakan bagi perusahaan dalam memilih dan menetapkan berbagai aktivitas yang harus dilakukan oleh perusahaan dalam penerapan GCG (Warsono et al, 2009:63). 


\section{Tabel 2 Definisi Prinsip-Prinsip GCG}

\section{Prinsip GCG}

Transparansi

Kemandirian

Akuntabilitas

Pertanggungjawaban

Kewajaran

\section{Definisi}

Keterbukaan dalam melaksanakan proses pengambilan keputusan dan keterbukaan dalam mengemukakan informasi materiil dan relevan bagi perusahaan.

Suatu keadaaan dimana perusahaan dikelola secara profesional tanpa benturan kepentingan dan pengaruh/tekanan dari pihak manapun yang tidak sesuai dengan pearturan perundang-undangan yang berlaku dan prinsip korporasi yang sehat.

Kejelasan fungsi, pelaksanaan dan pertanggungjawaban organ perusahaan sehingga pengelolaan perusahaan terlaksana secara efektif.

Kesesuaian didalam pengelolaan perusahaan terhadap peraturan perundang-undangan yang berlaku dan prinsip-prinsip perusahaan yang sehat.

Keadilan dan kesetaraan didalam memenuhi hak-hak stakeholder yang timbul berdasarkan perjanjian dan peraturan perundangundangan yang berlaku.

\section{Sumber : Keputusan Menteri BUMN No. KEP-117/M-MBU/2002}

Instrumen utama yang digunakan dalam proses analisis penelitian ini adalah Corporate governance self assessment checklist yang disusun oleh KNKG. Tujuan penyususnan Corporate governance self assessment checklist adalah sebagai alat penilaian mandiri bagi perusahaan-perusahaan di Indonesia guna mengetahui implementasi GCG di masing-masing perusahaan. Pertanyaan-pertanyaan yang disusun dalam corporate governance self assessment checklist tidak hanya ditujukan untuk memperoleh jawaban "ya" atau "tidak" tetapi menekankan pada proses implementasi GCG perusahaan. Jawaban untuk pertanyaan-pertanyaan dalam corporate governance self assessment checklist memiliki nilai nol dan sepuluh. Indikator dalam corporate governance self assessment checklist antara lain (Komite Nasional Kebijakan Governance, 2006) :

1. Nilai-nilai perusahaan, merupakan landasan moral dalam mencapai visi dan misi perusahaan. Nilai-nilai perusahaan pada dasarnya universal, namun dalam merumuskannya perlu disesuaikan dengan sektor usaha serta karakter dan letak geografis dari masing-masing perusahaan.

2. Hak pemegang saham, hak pemegang saham harus dilindungi dan dapat dilaksanakan sesuai peraturan perundang-undangan dan anggaran dasar perusahaan.

3. Dewan Komisaris, sebagai organ perusahaan yang bertugas dan bertanggungjawab melakukan pengawasan dan memberikan nasihat kepada Direksi serta memastikan bahwa perusahaan melaksanakan GCG.

4. Dewan Direksi, sebagai organ perusahaan yang bertugas dan bertanggungjawab dalam mengelola perusahaan.

5. Pemangku kepentingan, antara lain mereka yang memiliki kepentingan terhadap perusahaan dan mereka yang terpengaruh secara langsung oleh keputusan strategis dan operasional perusahaan serta masyarakat sekitar perusahaan. Perusahaan harus menjalin hubungan yang sesuai dengan asas kewajaran dan kesetaraan berdasarkan ketentuan yang berlaku bagi masing-masing pihak.

6. Pengungkapan, setiap perusahaan perlu membuat pernyataan tentang kesesuaian penerapan GCG dengan pedoman GCG dalam laporan tahunannya. 
7. Pedoman pelaksanaan GCG, pelaksanaan GCG perlu dilakukan secara sistematis dan berkesinambungan. Untuk itu diperlukan pedoman praktis yang dapat dijadikan acuan oleh perusahaan dalam implementasi GCG.

\section{Metode Penelitian}

Jenis penelitian yang digunakan adalah deskriptif kuantitatif, menurut Sekaran (2007:158) metode deskriptif dilakukan untuk mengetahui serta menjelaskan karakter variabel yang diteliti pada suatu kondisi. Tujuan penggunaan metode ini adalah untuk memberikan gambaran aspek-aspek yang relavan dengan fenomena dari perspektif seseorang, organisasi, orientasi industri dan lainnya. Sedangkan menurut Sugiyono (2012:11) metode kuantitatif diartikan sebagai "Metode penelitian yang berlandaskan pada filsafat positivisme, digunakan untuk meneliti pada populasi atau sampel tertentu, pengumpulan data menggunakan instrumen penelitian, analisis data bersifat kuantitatif/statistik, dengan tujuan untuk menguji hipotesis yang telah ditetapkan".

Variabel yang digunakan dalam penelitian ini adalah GCG dalam penerapannya oleh PT INTI. Skala yang digunakan adalah skala Guttman. Penelitian menggunakan skala Guttman dilakukan bila ingin mendapatkan jawaban yang tegas terhadap suatu permasalahan yang ditanyakan.

Tabel 3 Variabel Operasional

\begin{tabular}{|c|l|l|c|}
\hline Variabel & \multicolumn{1}{|c|}{ Subvariabel } & \multicolumn{1}{|c|}{ Indikator } & Skala \\
\hline \multirow{4}{*}{$\begin{array}{c}\text { Good } \\
\text { Corporate } \\
\begin{array}{c}\text { Governan } \\
\text { ce }\end{array}\end{array}$} & Transparansi & Pengungkapan & \\
\cline { 2 - 3 } & Kemandirian & Nilai-nilai perusahaan & \multirow{3}{*}{$\begin{array}{c}\text { Ordin } \\
\text { al }\end{array}$} \\
\cline { 2 - 3 } & Pertanggungjawa & Kinerja Dewan Direksi & \\
\cline { 2 - 3 } & ban & $\begin{array}{l}\text { Hak peramegang saham } \\
\text { Governance }\end{array}$ & \\
\cline { 2 - 3 } & Kewajaran & $\begin{array}{l}\text { Hubungan perusahaan dengan Pemangku } \\
\text { kepentingan }\end{array}$ & \\
\hline
\end{tabular}

Sekaran (2007:241) menjelaskan populasi adalah keseluruhan kelompok orang, peristiwa, atau hal lain yang di investigasi oleh peneliti. Populasi dalam penelitian ini adalah Divisi Hukum dan Kepatuhan PT INTI. Sedangkan sampel menurut Zikmund (2010:42) adalah bagian kecil dari anggota populasi yang diambil menurut prosedur tertentu sehingga dapat mewakili populasinya. Pada penelitian ini menggunakan metode sensus dimana seluruh anggota populasi dijadikan sebagai responden untuk memperoleh data penelitian. Populasi dalam penelitian ini adalah pegawai pada divisi Hukum dan Kepatuhan PT INTI yang berjumlah 12 orang. Untuk teknik pengumpulan data, penulis menggunakan dua sumber informasi yaitu sumber primer dan sumber sekunder. Sumber primer dalam penelitian ini didapat dari penyebaran kuesioner kepada responden penelitian yaitu pegawai yang berada pada Divisi Hukum dan Kepatuhan PT INTI, sedangkan data sekunder didapat dari studi pustaka dan dokumentasi.

Teknik analisis data dalam penelitian ini dilakukan dengan mentransformasikan hasil penelitian yang berupa nilai dari jawaban responden dengan menggunakan Skala Guttman menjadi angka-angka dalam bentuk persen (\%). Untuk interpretasi hasil perhitungan presentase, menggunakan ketentuan sebagaimana dijelaskan oleh Dean J Champion (Ulfa, 2011), sebagai berikut : 
1) $0 \%-25 \%$ berarti bahwa implementasi Good Corporate Governance (GCG) tidak memadai.

2) $26 \%$ - $50 \%$ berarti bahwa implementasi Good Corporate Governance (GCG) kurang memadai.

3) $51 \%$ - 75\% berarti bahwa implementasi Good Corporate Governance (GCG) cukup memadai.

4) $76 \%$ - 100\% berarti bahwa implementasi Good Corporate Governance (GCG) sangat memadai.

Untuk mengetahui tanggapan responden penelitian mengenai implementasi GCG pada PT INTI dilakukan dengan analisis statistik deskriptif. Statistik deskriptif adalah teknik analisis yang digunakan untuk menganalisa data dengan cara mendeskripsikan data yang telah terkumpul sesuai dengan hasil yang sebenarnya (Sugiyono, 2013:206). Setelah data ditabulasi dan dilakukan pengolahan selanjutnya hasil pengolahan tersebut digolongkan kedalam nilai jenjang dengan empat kriteria sesuai dengan ketentuan Champion.

\section{Hasil dan Pembahasan}

Hasil analisis berkaitan dengan tujuan untuk mendeskripsikan implementasi GCG oleh PT INTI. Kuesioner yang dibagikan kepada 12 responden telah terkumpul sejumlah sepuluh kuesioner yang menunjukkan tingkat pengembalian kuesioner adalah $83 \%$.

Dari lima subvariabel, empat subvariabel diantaranya berada pada kategori sangat memadai. Hanya satu subvariabel yang berada pada kategori cukup memadai yaitu subvariabel kemandirian. Seperti dijelaskan pada garis jenjang penilaian masing-masing subvariabel dari variabel GCG mulai dari persentase tertinggi sampai dengan yang terendah berikut ini :

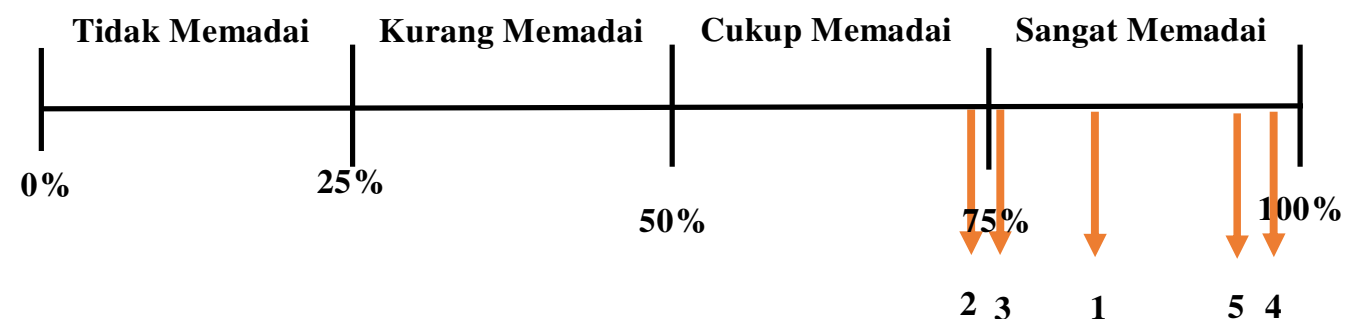

Gambar 1

Garis Nilai Jenjang Subvariabel GCG

Keterangan Gambar 1 :

$1=$ Transparansi $(83 \%)$

$2=$ Kemandirian $(74,44 \%)$

$3=$ Akuntabilitas $(75,65 \%)$

$$
\begin{aligned}
& 4=\text { Pertanggungjawaban }(98 \%) \\
& 5=\text { Kewajaran }(95 \%)
\end{aligned}
$$

\section{Pertanggungjawaban}

Subvariabel pertanggungjawaban memiliki presentase skor paling tinggi diantara keempat subvariabel lainnya sebesar 98\%. Hal ini menunjukan bahwa pertanggungjawaban berada pada kategori sangat memadai, berdasarkan pernyataan yang disampaikan dalam kuesioner PT INTI dalam pengelolaannya telah mematuhi kebijakan atau peraturan terkait prinsip-prinsip korporasi yang sehat, serta telah mampu mempertanggungjawabkan kebijakan 
Rudy Hartanto

Helni Mutiarsih Jumhur
Jurnal Manajemen Bisnis Indonesia

Vol. 3, Nomor 3, Juni 2016

perusahaan kepada seluruh stakeholders dengan berpegang pada prinsip pertanggungjawaban.

\section{Kewajaran}

Presentase skor yang diperoleh subvariabel kewajaran setelah melalui pengolahan data adalah 95\%. Penerapan prinsip kewajaran PT INTI telah mampu memberikan perlakuan yang setara kepada seluruh stakeholders seperti pemegang saham, kreditor, supplier, konsumen, karyawan, pemerintah, masyarakat dan lingkungan tentang ketentuan kerjasama, survei kepuasan, program pengembangan serta akses ke informasi lain terkait kepentingan masing-masing stakeholders.

\section{Transparansi}

Hasil analisis menunjukan subvariabel transparansi mendapatkan presentase skor sebesar 83\% yang menjelaskan bahwa implementasi prinsip transparansi pada PT INTI masuk kedalam kategori sangat memadai. Hal tersebut terlihat melalui kemudahan bagi stakeholders untuk mengakses informasi yang mereka butuhkan dan untuk menjaga objektivitas dalam menjalankan bisnis, pengungkapan informasi yang sesuai dengan apa yang terjadi dalam perusahaan telah dilaksanakan oleh PT INTI untuk mewujudkan penerapan prinsip transparansi dengan benar sesuai dengan prinsip-prinsip korporasi yang sehat dalam kegiatan operasional perusahaan.

\section{Akuntabilitas}

Subvariabel akuntabilitas memperoleh hasil presentase skor sebesar 75,65\%. Penerapan prinsip akuntabilitas yang dilaksanakan PT INTI termasuk dalam kategori sangat memadai. Berdasarkan hal tersebut pengelolaan PT INTI dapat dikatakan telah terlaksana secara efektif dan efisien melalui pelaksanaan fungsi serta tanggungjawab manajemen perusahaan yang profesional. Profesionalitas yang dibangun sebagai wujud penerapan prinsip akuntabilitas tercermin pada kode etik dan budaya yang dibangun PT INTI serta struktur organisasi yang secara jelas menggambarkan tugas, wewenang, dan tanggungjawab masingmasing pegawai dalam perusahaan.

\section{Kemandirian}

Subvariabel kemandirian memperoleh presentase skor paling rendah diantara keempat subvariabel lainnya yaitu sebesar 74,44\%. Meskipun memperoleh hasil presentase paling rendah akan tetapi penerapan prinsip kemandirian pada PT INTI masih sesuai karena tergolong dalam kategori cukup baik. Berdasarkan pernyataan yang disampaikan dalam kuesioner menggambarkan masih adanya potensi komisaris dan direksi serta jajaran perusahaan sering menerima hadiah dan donasi dari mitra bisnis, masih terjadi penyalahgunaan informasi perusahaan untuk kepentingan pribadi komisaris, direksi ataupun seluruh jajaran perusahaan yang dapat memicu terjadinya konflik kepentingan serta intervensi dari pihak-pihak yang bersangkutan baik dari internal maupun eksternal perusahaan. Prinsip kemandirian diwujudkan PT INTI antara lain melalui kebijakan perusahaan terkait benturan kepentingan, auditor independen, serta kebijakan tentang larangan dan penerimaan hadiah.

Pada analisis variabel GCG secara keseluruhan implementasi GCG pada PT INTI menghasilkan skor 83,70\%. Skor tersebut menunjukkan implementasi GCG masuk kedalam 
kategori sangat memadai. Dengan hasil tersebut dapat dikatakan PT INTI telah berhasil menerapkan GCG dalam pengelolaan perusahaan secara maksimal. Hal ini tentu akan mendukung perusahaan dalam pencapaian tujuan seperti yang tertera dalam Keputusan Menteri BUMN No. KEP-117/M-MBU/2002 tentang Penerapan Praktik GCG di BUMN terkait tujuan penerapan GCG dalam perusahaan.

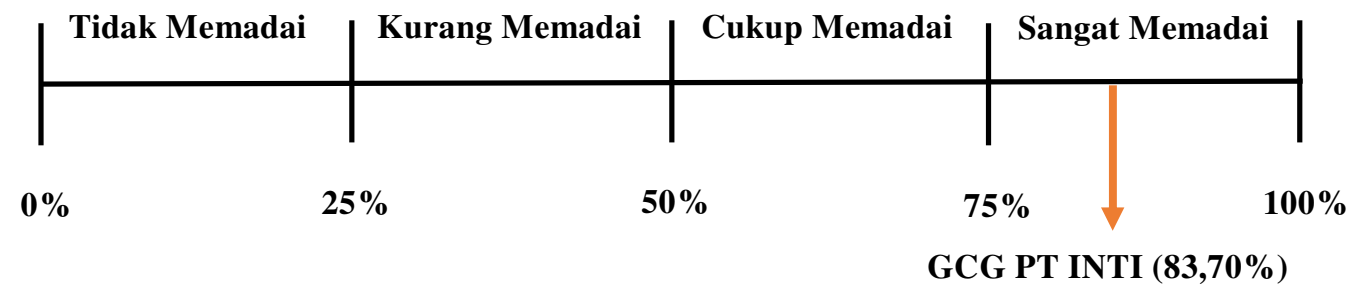

Gambar 2

Garis Nilai Jenjang Variabel GCG

Meskipun secara simultan implementasi GCG PT INTI telah berada pada kategori sangat memadai, akan tetapi jika ditinjau secara parsial terdapat satu subvariabel yang implementasinya dapat dikatakan belum maksimal karena masih berada pada kategori cukup memadai. Seperti telah dijelaskan sebelumnya subvariabel kemandirian adalah yang implementasinya belum maksimal. Untuk mampu mewujudkan nilai-nilai tata kelola perusahaan yang sehat tentunya PT INTI harus mengupayakan kelima prinsip GCG tersebut agar dapat masuk kedalam kategori sangat memadai.

Setelah pemaparan hasil penelitian, berikut dijelaskan pembahasan mengenai implementasi GCG berdasarkan hasil analisis data yang telah dilakukan melalui presentase skor yang didapat dari masing-masing subvariabel dan variabel GCG secara keseluruhan dalam implementasi GCG yang dilakukan oleh PT INTI.

1. Transparansi, prinsip pertama dalam implementasi GCG di PT INTI ini memperoleh presentase skor sebesar $83 \%$ yang tergolong kedalam kategori sangat memadai. Bukti dari implementasi prinsip transparansi dapat dilihat pada kegiatan yang dilaksanakan PT INTI seperti vendor gathering, komunikasi internal atau forum komunikasi karyawan, pemberdayaan website INTI untuk keterbukaan informasi, penerapan $E$ auction guna transparansi pengadaan barang dan jasa, serta publikasi laporan keuangan perusahaan.

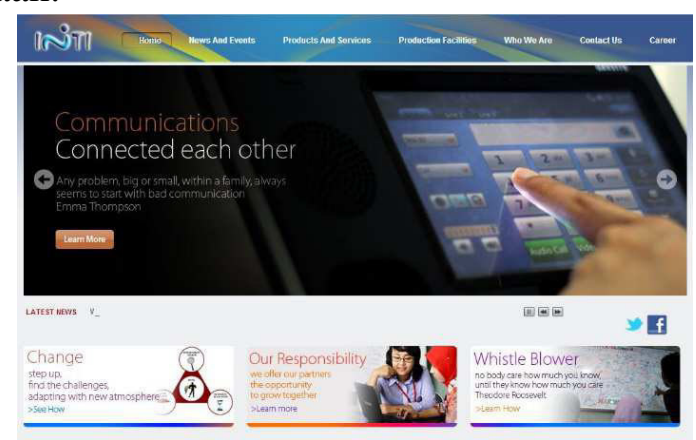

Gambar 3. Website PT INTI

Sumber : www.inti.co.id (diakses tanggal 21 Agustus 2014)

Gambar 3 menunjukan pemberdayaan website PT INTI guna keterbukaan informasi sebagai wujud implementasi prinsip transparansi dalam kegiatan bisnis perusahaan.

2. Kemandirian, prinsip kedua dalam perwujudan GCG di PT INTI ini memperoleh presentase skor sebesar $74,44 \%$ yang tergolong kedalam kategori cukup memadai. 
Implementasi prinsip kemandirian pada PT INTI digambarkan melalui auditor independen, RUPS, Kebijakan terkait benturan kepentingan, kebijakan pemberian donasi, dan kebijakan tentang larangan serta penerimaan hadiah. Prinsip kemandirian mendapatkan presentase skor paling rendah diantara prinsip-prinsip GCG lainnya yang mengindikasikan kurang maksimalnya upaya PT INTI dalam penerapan prinsip ini.

3. Akuntabilitas, prinsip ketiga dalam implementasi GCG di PT INTI ini memperoleh presentase skor sebesar $75,65 \%$ dan memasukannya dalam kategori sangat memadai. Penerapan prinsip akuntabilitas terlihat dari penentuan tugas dan tanggungjawab setiap lini perusahaan secara jelas dalam struktur organisasi. Selain itu, didukung pula dengan hadirnya kode etik dan budaya perusahaan dalam PT INTI, kemudian adanya key performance indicator, kebijakan terkait whistle blower serta implementasi ISO sebagai upaya untuk pengelolaan perusahaan yang efektif dan efisien sesuai visi dan misi yang diusung perusahaan.

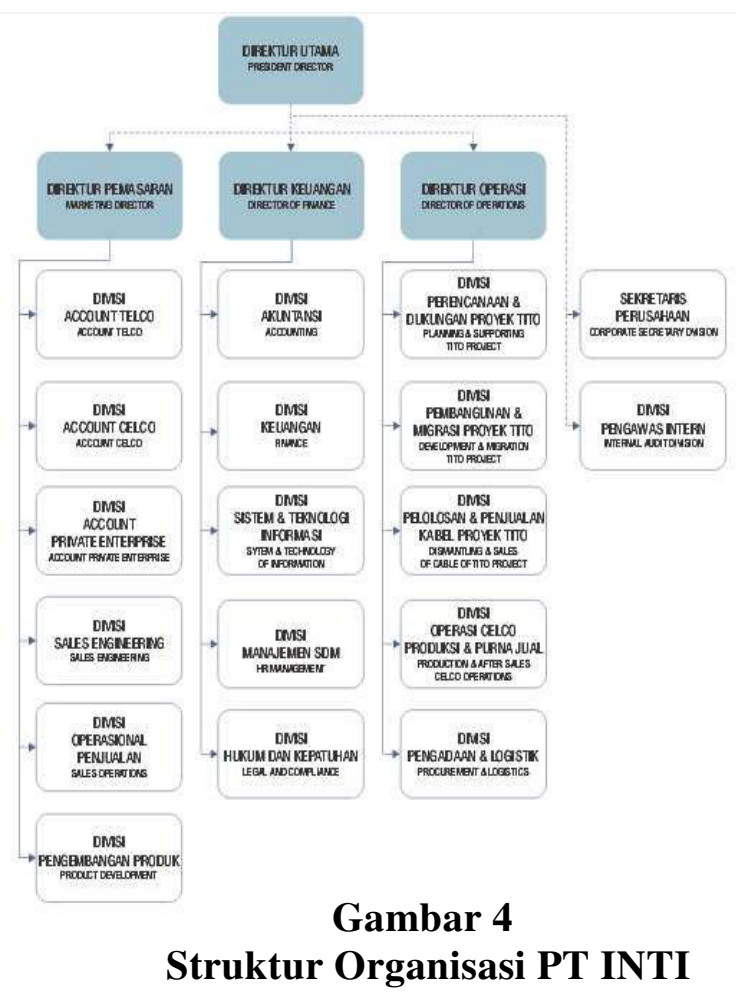

Sumber : www.inti.co.id (diakses tanggal 21 Agustus 2014)

Pada Gambar 4 menunjukan tugas dan tanggungjawab setiap lini dalam perusahaan secara jelas dalam bentuk struktur organisasi sebagai wujud implementasi prinsip akuntabilitas.

4. Pertanggungjawaban, prinsip keempat dalam perwujudan GCG di PT INTI ini memperoleh presentase tertinggi dengan skor sebesar $98 \%$ yang menggolongkannya kedalam kategori sangat memadai. Berdasarkan hasil tersebut pertanggungjawaban merupakan prinsip yang implementasinya paling optimal di PT INTI. Bukti dari implementasi prinsip pertanggungjawaban dapat dilihat dari kegiatan yang dilakukan PT INTI seperti laporan manajemen, anggaran dasar dan perubahannya, pengawasan 
internal, perbaikan kesejahteraan karyawan, program kemitraan dan bina lingkungan, serta kepatuhan terhadap peraturan perundang-undangan.

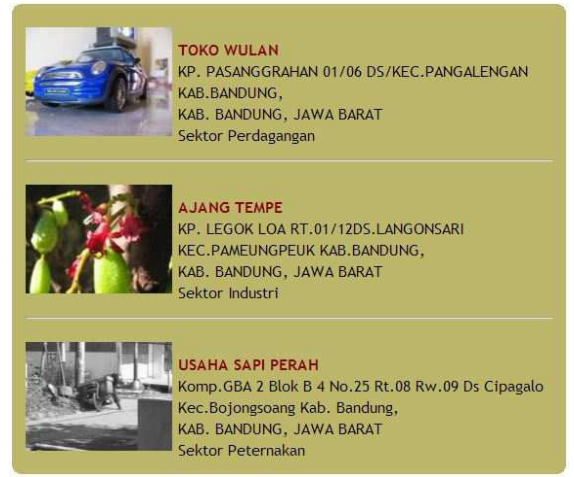

\section{Gambar 5 \\ Mitra Binaan PT INTI}

Sumber : www.pkblinti.org/modules/mitrabinaan (diakses tanggal 21 Agustus 2014)

Pada Gambar 5 menjelaskan beberapa mitra binaan PT INTI yang juga menjadi salah satu perwujudan implementasi prinsip pertanggungjawaban dengan pelaksanaan Program Kemitraan dan Bina Lingkungan (PKBL) INTI sebagaimana diatur dalam Peraturan Menteri Badan Usaha Milik Negara RI No. PER-5/MBU/2007 tentang Program Kemitraan Badan Usaha Milik Negara dengan Usaha Kecil dan Program Bina Lingkungan.

5. Kewajaran, adalah prinsip kelima dalam implementasi GCG di PT INTI. Prinsip kewajaran memperoleh presentase skor sebesar 95\%. Bukti implementasi dari prinsip kewajaran dapat dilihat dari kegiatan perusahaan antara lain perjanjian kerjasama, sistem karir, e-auction, dan job tender. Dengan hasil itu pula dapat dikatakan PT INTI telah mampu menghadirkan kesetaraan terhadap seluruh stakeholders.

Berdasarkan hasil analisis penghitungan terhadap variabel GCG secara keseluruhan melalui penentuan bobot pada masing-masing subvariabel sesuai dengan GCG self assessment checklist oleh KNKG, implementasi GCG pada PT INTI memperoleh skor sebesar 83,70\%. Jumlah skor tersebut menggolongkan implementasi GCG pada PT INTI kedalam kategori sangat memadai. PT INTI telah melaksanakan GCG sejak tahun tahun 2004. Implementasi GCG pada PT INTI berpedoman pada Keputusan Menteri BUMN No. KEP-117/M-MBU/2002 tentang Penerapan Praktik GCG di BUMN. Pelaksanaan penerapan GCG oleh PT INTI diatur secara sistematis melalui Road Map GCG INTI yang dimulai dengan langkah membentuk Komite Tata Kelola Perusahaan (GCG).

\section{Kesimpulan dan Saran}

Berdasarkan hasil penelitian dan pembahasan yang telah diuraikan pada bab sebelumnya, maka dapat ditarik kesimpulan sebagai berikut :

1. Implementasi GCG yang dilaksanakan PT INTI jika dilihat melalui analisis secara parsial dan diurutkan dari prinsip yang memiliki jumlah presentase skor yang paling tinggi adalah prinsip pertanggungjawaban, kemudian prinsip kewajaran, prinsip transparansi, prinsip akuntabilitas dan yang memperoleh presentase skor paling rendah adalah prinsip kemandirian, serta hanya prinsip kemandirian yang tergolong dalam kategori cukup memadai sedangkan ke empat prinsip lainnya berada pada 
kategori sangat memadai. Hasil tersebut dapat dikatakan mewakili pendapat responden yang menggambarkan bahwa implementasi kelima prinsip GCG pada PT INTI telah memadai. Prinsip pertanggungjawaban mendapat penilaian yang paling memadai implementasinya sedangkan prinsip kemandirian mendapatkan penilaian yang kurang dibandingkan dengan prinsip lainnya.

2. Implementasi GCG yang dilaksanakan PT INTI jika dilihat dari analisis secara simultan sesuai dengan penghitungan dalam GCG self assessment checklist yang disusun oleh KNKG mendapatkan skor sebesar 83,70\%. Skor tersebut menggolongkan implementasi GCG pada PT INTI kedalam kategori sangat memadai. Dari hasil tersebut dapat mewakili pendapat responden yang menggambarkan bahwa implementasi GCG yang dilaksanakan PT INTI telah memadai. Implementasi GCG pada PT INTI yang telah memadai tercermin dari kegiatan sehari-hari perusahaan seperti pemberdayaan website PT INTI guna ketrebukaan informasi, Program Kemitraan dan Bina Lingkungan untuk memenuhi tanggungjawab sosial perusahaan serta pengaturan pelaksanaan GCG secara sistematis melalui Road Map GCG INTI.

Berdasarkan hasil analisis dan pembahasan dalam penelitian, maka saran yang dapat disampaikan sebagai bahan masukan dan pertimbangan yang dapat berguna bagi PT INTI ataupun pihak lain adalah sebagai berikut :

1. Penelitian ini memiliki keterbatasan pada kelima prinsip GCG untuk mengungkapkan implementasi GCG dalam perusahaan, karena itu perlu dilakukan penelitian lanjutan mengenai variabel-variabel lain yang dapat menjelaskan implementasi GCG lebih lanjut misalnya dibahas juga mengenai Corporate Social Responsibility (CSR) dalam perusahaan sehingga hasil penelitian dapat semakin luas.

2. Instrumen penelitian yang digunakan yaitu Corporate governance self assessment checklist memiliki kelemahan berupa subjektifitas data, karena itu guna mendukung tingkat keabsahan data yang lebih baik untuk penelitian selanjutnya dapat menggunakan instrumen tambahan seperti melakukan wawancara lebih mendalam atau dapat juga dengan melakukan observasi yang lebih mendalam terkait pelaksanaan GCG disebuah perusahaan.

3. Pada implementasi prinsip kemandirian yang dilaksanakan PT INTI memiliki hasil yang paling rendah dan menjadi satu-satunya prinsip yang pelaksanaannya masuk dalam kategori cukup memadai. Hal tersebut menggambarkan penilain responden bahwa implementasi prinsip kemandirian pada PT INTI harus dilaksanakan dengan lebih maksimal, misalnya dengan meningkatkan kepatuhan terhadap kebijakankebijakan perusahaan terkait prinsip kemandirian seperti kebijakan pemberian donasi dan kebijakan tentang larangan serta penerimaan hadiah. Melalui hal tersebut diharapkan implementasi GCG pada PT INTI dapat lebih optimal untuk kedepannya dengan tetap mempertahankan serta meningkatkan implementasi GCG untuk mewujudkan tata kelola perusahaan yang sehat dan mendukung kegiatan bisnis PT INTI menuju tujuan yang telah ditetapkan oleh perusahaan.

\section{Daftar Pustaka}

Effendi, Muh. Arief. (2009). The Power of Good Corporate Governance : Teori dan Implementasi. Jakarta : Salemba Empat.

Komite Nasional Kebijakan Governance. (2006). Pedoman Umum Good Corporate Governance Indonesia. Jakarta : Komite Nasional Kebijakan Governance. 
Rudy Hartanto

Helni Mutiarsih Jumhur
Jurnal Manajemen Bisnis Indonesia Vol. 3, Nomor 3, Juni 2016

Mukharomah, Wafiatun. (2010). Meningkatkan Kinerja Perusahaan Melalui Praktek Corporate Governance pada Industri Kecil dan Menengah. Jurnal Manajemen dan Bisnis Vol. 14 No. 2. Surakarta : Universitas Muhammadiyah Surakarta.

Retno, Reni Diah dan Denies Priantinah. (2012). Pengaruh Good Corporate Governance dan Pengungkapan Corporate Social Responsibility Terhadap Nilai Perusahaan (Studi Empiris Pada Perusahaan yang Terdaftar di Bursa efek Indonesia Periode 20072010). Jurnal Nominal Vol. 1 No. 1. Yogyakarta : Fakultas Ekonomi Universitas Negeri Yogyakarta.

Sekaran, Uma. (2007). Research Methods for Business. Jakarta : Salemba Empat.

Siregar, Syofian. (2013). Metode Penelitian Kuantitatif (Dilengkapi dengan Perbandingan Perhitungan Manual dan SPSS). Jakarta : Kencana Prenada Media Group.

Sugiyono. (2013). Metode Penelitian Bisnis. Bandung : Alfabeta.

Sutedi, Adrian. (2011). Good Corporate Governance. Jakarta : Sinar Grafika.

Ulfa, Umi Maria. (2011). Evaluasi Sistem Pegendalian Intern Pengeluaran Kas Pada PT Global Engineering Technology Jakarta. Jurnal Akuntansi Vol. 11 No. 2. Semarang : Universitas Diponegoro

Warsono, Sony; Fitri Amalia, dan Dian Kartika Rahajeng. (2009). Corporate Governance Concept and Model: Preserving True Organization Welfare. Yogyakarta : Center for Good Corporate.

Zikmund, William G; Barry J. Babin, Jon C. Carr, Mitch Griffin. (2010). Business Research Method 8th Edition. Canada : Cengage Learning.

www.inti.co.id (diakses tanggal 19 Februari dan 21 Agustus 2014)

www.pkblinti.org/modules/mitrabinaan (diakses tanggal 21 Agustus 2014) 